\title{
Diversity of Underground Medicinal and Aromatic Plants and their Regeneration for Further Ex situ Conservation in Herbal Garden
}

\section{Patel DK*}

Department of Rural Technology, Guru Ghasidas Vishwavidyalaya, (A Central University), Bilaspur, 495009, Chhattisgarh, India

\begin{abstract}
Plants include a variety of useful substances for human beings and are widely used for treatment of various disorders. Plants are propagated mostly by their seeds but stem cutting also found to be useful for this purpose. Except of above methods some plants are also propagating through their modified root or stem found commonly inside of the soil or underground part of the plant. Some examples are Rhizome, Bulb, Tuber, corm etc. These structures are modified form and useful to regenerate the plants in favorable environmental condition. During of adverse condition these are found in resting phase and when moisture level increase new buds are produced by nodular part of them which performing efficient capability to reproducing the new plants as their parental ones. 42 Medicinal and aromatic plants underground parts were collected in different part of the Chhattisgarh and propagated in Herbal Garden in poly bags and also direct in the prepared beds. Developed new individuals of these plants in poly bags were carefully shifted to the prepared field for their further growth and development. As per need of the newly developing plants necessary facilities were provided.
\end{abstract}

Keywords: Ex situ conservation; Diversity; Medicinal and aromatic plants; Underground parts; Herbal Garden

\section{Introduction}

Plants are valuable components of the global biodiversity. Among a large group of the plants many plants are significantly performing their applicability in multifold utility for human beings. These are a major source of the food, fodder, fuel and also categorized for the use as medicine these group of the plants are referred as a Medicinal and Aromatic Plants.

Diversity, presence, mode of utilization, propagation modes etc. are differs from plants species to species. It is directly or indirectly affected by various factors like local environmental condition, Available facilities required for the growth and development of the plants as well as their genetic makeup.

Various plant parts like root, stem, and leaf are useful for specific purpose such as for medicinal value or for propagation. Modified plant parts like Bulb, Tuber, Rhizome, Corm etc. are also registered as useful plant parts for certain species. These structures are found to be useful for propagation as alternative source of the seeds and used for medicinal values. Mode of their utilization is variable.

Day by day due to climatic changes, increasing population load, over exploitation etc. are becoming major reasons for loss of the species in different habitat. Valuable plant parts which located inside of the soil are referred as Underground plants. These are mostly regenerated by their modified underground structures like Bulb, Tuber, Rhizome, Corm etc.

Some Medicinal and Aromatic plants are propagating by both the modes like by seeds as well as by underground plant parts like Asparagus racemosus. So in current scenario there is an urgent need for their assessment, regeneration and conservation for future generation.

Present study focuses on the collection/Propagation of the diverse underground Medicinal and Aromatic plants. Among the introduced Underground Medicinal and Aromatic plants some are endangered need for much care and conservation.

Ethno-medicinal Study/Use of medicinal plants of these plants were made by Abhyankar and Upadhyay [1], Agarwal [2], Sharma and
Kumar [3], Wagh and Jain [4], Swarnakar and Katewa [5], Savithramma et al. [6], Jyothi et al. [7], Shajeela et al. [8], Sheikh et al. [9], Sujatha and Renuga [10].

Documentation of Wild tuberous plants was carried out by Prashanth and Shiddamallayya [11]. Conservation strategy for Gloriosa superva Linn was made by Singh et al. [12] whereas conservation of highly exploited medicinal plants of Vindhyam range (U.P.) studied by Singh et al. [13]. Conservation and cultivation of threatened and high valued medicinal plants in north East India carried out by Shankar and Rawat [14]. Review on a tuberous, endangered medicinal plant was done by Ade and Rai [15].

\section{Materials and Methods}

Underground plant parts like Bulb, Tuber, Rhizome, Corms were collected / removed from soil and carried out in Herbal Garden for their further regeneration. Underground plant parts were collected and shade dry was applied for their storage and for control on bud/ root initiation. When it gets favorable environmental condition it starts their growth.

Above parts were primarily initiated the origination of new buds/roots for this purpose these are put in cotton/jute clothes with proper water management. After initiation of the new buds of the underground parts were selected for further development. Each part of the underground parts used for this purpose selected by the presence of one, two buds and are carefully removed from the mother plants. These plant parts were deep in soil in moderate depth than cover by using

*Corresponding author: Patel DK, Department of Rural Technology, Guru Ghasidas Vishwavidyalaya, (A Central University), Bilaspur, 495009, Chhattisgarh, India, Tel: +91-9993660173; E-mail: dplantscience@yahoo.co.in

Received November 04, 2014; Accepted March 01, 2015; Published March 09 , 2015

Citation: Patel DK (2015) Diversity of Underground Medicinal and Aromatic Plants and their Regeneration for Further Ex situ Conservation in Herbal Garden. J Biodivers Endanger Species 3: 152. doi:10.4172/2332-2543.1000152

Copyright: ( 2015 Patel DK. This is an open-access article distributed under the terms of the Creative Commons Attribution License, which permits unrestricted use, distribution, and reproduction in any medium, provided the original author and source are credited. 
Citation: Patel DK (2015) Diversity of Underground Medicinal and Aromatic Plants and their Regeneration for Further Ex situ Conservation in Herbal Garden. J Biodivers Endanger Species 3: 152. doi:10.4172/2332-2543.1000152

Page 2 of 3

soil mixing with sand and manure. Light irrigation applied in planted these plant parts.

As per need of the Medicinal and Aromatic Plants water, nutrient etc. were provided and protected the plant against diseases, insect pest etc. effect. Excess water removal facility was also carried out for protection of these structures against its decay.

\section{Results and Discussion}

Collected varied underground plant parts were stored in shade and dry places in summer season and during of starting of rains these are applied for development of new buds which are efficient to develop into new individuals as their parental ones.

Results of the current research is shown in Table 1 that includes each plants Common name, Botanical names, Family, Habit, Propagation and mode of multiplication. Table 2 is for distribution of the Medicinal and Aromatic plants according to their families individually. Maximum members of the family Liliaceae 13 plant species were propagated, secondly 09 species of the family Zingiberaceae was propagated by Rhizomes. Rests of the plants belonging to listed families were propagated 01-04 plant species separately.

\begin{tabular}{|c|c|c|c|c|c|c|}
\hline S. No. & Common Name & Botanical Name & Family & Habit & Propagation & $\begin{array}{l}\text { Mode of Multi- } \\
\text { plication }\end{array}$ \\
\hline 1 & Adarak/Zinger & Zinziber officinale Rose. & Zingiberaceae & Herb & Rhizome & Poly Bags \\
\hline 2 & Air Potato & Dioscoria bulbifera Linn. & Dioscoriaceae & Herb/Climber & Tuber & Poly Bags \\
\hline 3 & Ama Adarak, Mango ginger & Curcuma amada Roxb. & Zingiberaceae & Herb & Rhizome & Poly Bags \\
\hline 4 & Banana & Musa paradicica Linn. & Musaceae & Herb & Rhizome & Field \\
\hline 5 & Beet & Beta vulgaris $\mathrm{L}$. & Amaranthaceae & Herb & Seed & Field \\
\hline 6 & Black Turmeric & Curcuma caesia Roxb. & Zingiberaceae & Herb & Rhizome & Poly Bags \\
\hline 7 & Blue ginger & Alpinia galanga (L.) Willd. & Zingiberaceae & Herb & Rhizome & Poly Bags \\
\hline 8 & Canna & Canna indica Linn. & Zingiberaceae & Herb & Rhizome & Poly Bags \\
\hline 9 & Canyon morning-glory & Ipomoea barbatisepala A. Gray. & Convolvulaceae & Herb & Tuber/Stem cutting & Field \\
\hline 10 & Cylindrical Snake Plant & Sensiveria cylindrica Bojer. & Agavaceae & Herb & Rhizome & Poly Bags \\
\hline 11 & Easter lily & Hippeastrum puniceum (Lam.) Vossl. & Amaryllidaceae & Herb & Bulb & Field \\
\hline 12 & Football lily & Scadoxus multiflorus (Martyn) Raf. & Liliaceae & Herb & Bulb & Field \\
\hline 13 & Four o' clock plant & Mirabilis jalapa Linn. & Nyctaginaceae & Herb & Seed/ Stem cutting/Tuber & Poly Bags \\
\hline 14 & Garlic & Allium sativum Linn. & Liliaceae & Herb & Bulb & Poly Bags \\
\hline 15 & Gulbacauli & $\begin{array}{l}\text { Hedychium coronarium } \\
\text { J. Koenig }\end{array}$ & Zingiberaceae & Herb & Rhizome & Field \\
\hline 16 & Haldi & Curcuma longa Linn. & Zingiberaceae & Herb & Rhizome & Poly Bags \\
\hline 17 & Kali Musli & Curculigo orchioides Gaerth. & Hypoxidaceae & Herb & Rhizome & Poly Bags \\
\hline 18 & Kalihari, Glory Lili & Gloriosa superva Linn. & Liliaceae & Herb & Tuber & Poly Bags \\
\hline 19 & Keukand & Costus speciosus (J. Konig) Sm. & Liliaceae & Herb & Rhizome & Poly Bags \\
\hline 20 & Muli & Raphanus sativus L. & Brassicaceae & Herb & Seed & Field \\
\hline 21 & Nagarmotha & Cyperus rotundus Linn. & Cyperaceae & Herb & Rhizome & Field \\
\hline 22 & Onion & Allium cepa Linn. & Liliaceae & Herb & Bulb & Poly Bags \\
\hline 23 & Pink rain lily & Zephyranthes rosea Lindl. & Amaryllidaceae & Herb & Bulb & Poly Bags \\
\hline 24 & Rajnigandha & Polyanthus tuberosa Linn. & Amaryllidaceae & Herb & Tuber & Poly Bags \\
\hline 25 & Ram dauton & Smilax Chinensis Linn. & Smilacaceae & Shrub & Rhizome & Field \\
\hline 26 & Safed Musli & Chlorophytum borivilianum San. \& Fer. & Liliaceae & Herb & Bulb & Field \\
\hline 27 & Safed Musli & Chlorophytum borivillionam San. \& Fer. & Liliaceae & Herb & Rhizome & Poly Bags \\
\hline 28 & Satavar & Asparagus racemosus Willd. & Liliaceae & Herb/Climber & Seed/Tuber & Poly Bags \\
\hline 29 & Sisal Hemp & Agave sesalana Perr. & Agavaceae & Shrub & Rhizome & Poly Bags \\
\hline 30 & Small Arbi & Colocasia esculenta (L) Schott & Araceae & Herb & Corm & Poly Bags \\
\hline 31 & Snake Plant & Sensiveria trifaciata Prain. & Agavaceae & Herb & Rhizome & Poly Bags \\
\hline 32 & Spider lily & Crinum latifolium Linn. & Liliaceae & Herb & Bulb & Field \\
\hline 33 & Sudarshan & Crinum latifolium Linn. & Liliaceae & Herb & Bulb & Poly Bags \\
\hline 34 & Sudersan & Linnum usitatissium Linn. & Liliaceae & Herb & Bulb & Poly Bags \\
\hline 35 & Sweet flag & Acorus calamus Linn. & Araceae & Herb & Rhizome & Poly Bags \\
\hline 36 & Sweet potato & Ipomoea batatas Linn. & Convolvulaceae & Herb & Tuber/Stem cutting & Field \\
\hline 37 & Tikhur & Curcuma angustifolia. & Zingiberaceae & Herb & Rhizome & Poly Bags \\
\hline 38 & Wild Onion & Allium canadense Linn. & Liliaceae & Herb & Bulb & Poly Bags \\
\hline 39 & Wild garlic & Allium vineale Linn. & Liliaceae & Herb & Bulb & Poly Bags \\
\hline 40 & Wild Zinger & Curcuma aromtica Linn. & Zinziberaceae & Herb & Rhizome & Field \\
\hline 41 & Zimi kand & Amorphophallus dubius Linn. & Araceae & Herb & Corm & Poly Bags \\
\hline 42 & Zimikand & $\begin{array}{l}\text { Amorphophallus paeoniifolius } \\
\text { (Dennst.) Nicolson }\end{array}$ & Araceae & Herb & Corm & Field \\
\hline
\end{tabular}

Table 1: Underground medicinal and aromatic plants (MAPs) and their regeneration in herbal garden. 
Citation: Patel DK (2015) Diversity of Underground Medicinal and Aromatic Plants and their Regeneration for Further Ex situ Conservation in Herbal Garden. J Biodivers Endanger Species 3: 152. doi:10.4172/2332-2543.1000152

Page 3 of 3

\begin{tabular}{|c|c|c|c|c|c|}
\hline S. No. & Family & Herb & Shrub & Tree & Total \\
\hline 1 & Agavaceae &,++ & + & - & 3 \\
\hline 2 & Amaranthaceae & + & - & - & 1 \\
\hline 3 & Amaryllidaceae &,,+++ & - & - & 3 \\
\hline 4 & Araceae &,,,++++ & - & - & 4 \\
\hline 5 & Brassicaceae & + & - & - & 1 \\
\hline 6 & Convolvulaceae &,++ & - & - & 2 \\
\hline 7 & Cyperaceae & + & - & - & 1 \\
\hline 8 & Dioscoriaceae & + & - & - & 1 \\
\hline 9 & Hypoxidaceae & + & - & - & 1 \\
\hline 10 & Liliaceae & $\begin{array}{c}+,+,+,+,+,+,+ \\
+,+,+,+,+,+\end{array}$ & - & - & 13 \\
\hline 11 & Musaceae & + & - & - & 1 \\
\hline 12 & Nyctaginaceae & + & - & - & 1 \\
\hline 13 & Smilacaceae & - & + & - & 1 \\
\hline 14 & Zingiberaceae & $\begin{array}{c}+,+,+,+,+,+,+ \\
+,+\end{array}$ & - & - & 9 \\
\hline \multicolumn{5}{|c|}{ TOTAL } & 42 \\
\hline
\end{tabular}

Table 2: Family wise distribution of aromatic plants.

\begin{tabular}{|c|c|c|}
\hline S. No. & Mode of Multiplication & Number \\
\hline 1 & Bulb & 11 \\
\hline 2 & Corm & 3 \\
\hline 3 & Rhizome & 19 \\
\hline 4 & Seed & 2 \\
\hline 5 & Seed/Tuber & 1 \\
\hline 6 & Seed/ Stem cutting/Tuber & 1 \\
\hline 7 & Tuber/Stem cutting & 2 \\
\hline 8 & Tuber & 3 \\
\hline & Total & $\mathbf{4 2}$ \\
\hline
\end{tabular}

Table 3: Multiplication methods of MAPs.

\begin{tabular}{|c|c|c|}
\hline S. No. & Habit Type & Number of the Aromatic Plants \\
\hline 1 & Herb & 38 \\
\hline 2 & Shrub & 02 \\
\hline 3 & Herb/Climber & 02 \\
\hline & Total & $\mathbf{4 2}$ \\
\hline
\end{tabular}

Table 4: Diversity in habit of the underground medicinal and aromatic plants.

Used plant parts for propagation of different Medicinal and Aromatic plants were recorded in variable modes and numbers listed in Table 3. Rhizome is used to propagate 19 plant species, 11 species by Bulbs and rest modes were applied for different species of the Medicinal and Aromatic plants.

Table 4 is for diversity in habits of the introduced plant species. 38 species are regenerated for maximum herbs, 02 - 02 plant species were for Shrubs and Herb/climber during the tenure of the present study.

\section{Acknowledgement}

The current work is supported by UGC New Delhi under Start up Grant for carrying out research in the field of/ Topic "Ex situ Conservation of important Medicinal and Aromatic Plants (MAPs) Resources from Chhattisgarh in Guru Ghasidas Vishwavidyalaya (A Central University) Campus, Bilaspur (C.G.)" No. F. 20 - 17 (3)/2012 (BSR) - Dated 8 March 2013.

\section{References}

1. Abhyankar RK, Upadhyay R (2011) Ethnomedicinal Studies of Tubers of Hosangabad M. P. Bulletin of Environment, Pharmacology and Life Sciences 1: $57-59$.

2. Agarwal $P$ (2013) Medicinal importance of underground plant parts from Fatehpur district, Uttar Pradesh, India. International Journal of Pharmacy and Life Sciences 4: 2731-2734.

3. Sharma S, Kumar A (2012) Herbal Medicinal plant of Rajasthan: Musli. International Journal Life Sciences and Pharma Research 2: 62-68.

4. Wagh VV, Jain AK (2014) Ethno-medicinal uses of Underground plant parts in Jhbua district of Madhya Pradesh, India. 8: 151-156.

5. Swarnakar S, Katewa SS (2008) Ethno-botanical observation on tuberous plants from tribal area of Rajasthan (India). Ethno-botanical Leaflets 12: 647666.

6. Savithramma N, Ankanna S, Rao ML, Saradvathi J (2012) Studies on antimicrobial efficacy of medicinal tuberous shrub Talinum cuneifolium. J Environ Biol 33: 775-780.

7. Jyothi B, Pratap GP, Sudarsanam S, Sitaram B, Vasudha K (2011) Life Sciences Leaflets 18: 695-699.

8. Shajeela PS, Mohan VR, Jesudhas LL (2010) Medicinal plants used by the Kanikkars of Kanyakumari district, Tamil Nadu. Asian J Exp Biol Sci 1: 624-626.

9. Sheikh N, Kumar Y, Misra AK, Pfoze L (2013) Photochemical screening to validate the ethno-botanical importance of root tubers of Dioscoria species of Meghalaya, North east India. Journal of Medicinal plants studies 1: 62-69.

10. Sujatha S, Renuga FB (2013) Medicinal and edible tubers from fourty two settlements of tribals from Pechiparai social forest in Kanyakumari district, India. Scholars Academic Journal of Biosciences 1: 213-216.

11. Prashanth Kumar GM, Shiddamallayya N (2014) Documentation of wild plan tubers as food resources in Hassan district, Karnataka. International Journal of applied biology and pharmaceutical technology. 5: 90-95.

12. Singh D, Mishra M, Yadav AS (2013) Conservation strategy for Gloriosa superva Linn. International Journal of Botany and Research 3: 19-26.

13. Singh MP, Narayan J, Singh TN (2012) Conservation of highly exploited medicinal plants of Vindhyam range (U. P). Indian Journal of Life Sciences 1 : $55-56$

14. Shankar R, Rawat MS (2013) Conservation and cultivation of threatened and high valued medicinal plants in north East India. International Journal of Biodiversity and Conservation 5: 584-591.

15. Ade R, Rai MK (2009) Review: Current advances in Gloriosa superva Linn. Biodiversity 10: 210-214 